\title{
Serum lipid profile and hepatic evaluation in mice fed diet containing pequi nut or pulp (Caryocar brasiliense Camb.)
}

\author{
Perfil lipídico sérico e avaliação hepática em camundongos alimentados com dieta contendo amêndoa ou \\ polpa de pequi (Caryocar brasiliense Camb.)
}

\author{
Edenil Costa AGUILAR ${ }^{1 *}$, Maria das Graças Mota Nobre QUEIROZ², \\ Dario Alves de OLIVEIRA ${ }^{2}$, Neide Judith Faria de OLIVEIRA ${ }^{3}$
}

\begin{abstract}
Caryocar brasiliense (popular name pequi) is widely consumed by the population of Brazilian Savannah. This fruit has a high concentration of monounsaturated fatty acids that can influence positively the lipid profile. In addition, pequi also has an important concentration of saturated fatty acids which, in turn, is associated with atherosclerosis risk. This study aimed to investigate the effect of a pequi-supplemented diet on blood lipid and glucose levels and hepatic histology. Female Albino swiss mice were divided into three groups and fed a standard chow diet (control group), chow diet supplemented with 33\% pequi nut (nut group), and chow diet supplemented with $33 \%$ pequi pulp (pulp group). After 6 weeks, following an overnight fast, blood and liver were collected for posterior analyses. Serum total cholesterol and HDL-cholesterol were significantly higher in mice fed pequi-rich diets compared to the control group. Nevertheless, there was no modification in blood triglycerides, atherogenic fraction, and glucose levels. In addition, there was development of liver microvesicular steatosis related to pequi intake. In conclusion, the diets supplemented with pequi nut or pulp reduced the atherogenic risk by increasing the anti-atherogenic lipoproteins without changing the pro-atherogenic fraction in mice.
\end{abstract}

Keywords: lipids; diet; atherosclerosis; monounsaturated fatty acid.

\section{Resumo}

O Caryocar brasiliense (popularmente chamado pequi) é amplamente consumido pela população do Cerrado. Este fruto tem alta concentração de ácidos graxos monoinsaturados que podem influenciar positivamente o perfil lipídico. Não obstante, o pequi também possui uma importante concentração de ácidos graxos saturados, que, por sua vez, estão relacionados com o risco de aterosclerose. Este trabalho objetivou estudar o efeito de uma dieta suplementada com pequi sobre os níveis lipídicos e glicêmicos sanguíneos e histologia hepática. Camundongos Albino swiss fêmeas foram divididos em três grupos e alimentados com ração comercial (grupo controle), ração comercial suplementada com 33\% de amêndoa de pequi (grupo amêndoa) e ração comercial suplementada com 33\% de polpa de pequi (grupo polpa). Após 6 semanas, e jejum overnight, sangue e fígados foram coletados para análises posteriores. O colesterol total e HDL-colesterol séricos foram significativamente maiores nos camundongos alimentados com dietas contendo pequi, quando comparado ao grupo controle. Todavia, não houve modificação nos níveis sanguíneos de triglicérides, fração aterogênica e glicose. Além disso, houve desenvolvimento de esteatose microvesicular no fígado relacionada à ingestão de pequi. Em conclusão, as dietas suplementadas com polpa ou amêndoa de pequi diminuíram o risco aterogênico por aumentar as lipoproteínas antiaterogênicas sem mudar a fração pró-aterogênica nos camundongos.

Palavras-chave: lipídios; dieta; aterosclerose; ácidos graxos monoinsaturados.

\section{Introduction}

Consumption of fat-rich diet directly affects the serum lipid profile and the fatty acids composition, which is an important factor in the modulation of lipid metabolism. The high saturated fatty acids intake increases the low-density lipoprotein cholesterol (LDL-c) and reduces the high-density lipoprotein cholesterol (HDL-c) in the bloodstream. This is a known condition for the development of coronary artery disease because the HDL-c is inversely related to risk of atherosclerosis, while LDL-c is an important risk factor to cardiovascular events since, when present in elevated levels in the blood, it migrates to the arterial intimal layer triggering the development of atherosclerosis (PUIGGRÓS et al., 2002; ÁGUILA et al., 2002; GERMAN; DILLARD, 2004). Therefore, a balance of unsaturated fatty acids is important when selecting food sources and those rich in monounsaturated and polyunsaturated fatty acids; particularly, the long-chain n-3 polyunsatured fatty acids should be used preferentially since they reduce the risk for atherosclerosis (BINKOSKI et al., 2005; CASÓS et al., 2008).

\section{Received 18/11/2009}

Accepted 9/7/2010 (004538)

Laboratório de Aterosclerose e Bioquímica Nutricional, Departamento de Bioquímica e Imunologia, Universidade Federal de Minas Gerais - UFMG,

Av. Presidente Antônio Carlos, 6627, Pampulha, CEP 31270-901, Belo Horizonte, MG, Brasil, e-mail: edenilcostaaguilar@yahoo.com.br

2 Departamento de Biologia Geral, Universidade Estadual de Montes Claros - UNIMONTES, Campus Universitário Professor Darcy Ribeiro, Vila Mauricéia, CP 126, CEP 39401-089, Montes Claros, MG, Brasil

${ }^{3}$ Instituto de Ciências Agrárias, Morfologia Animal, Farmacologia e Toxicologia para a Produção Animal e de Alimentos, Universidade Federal de Minas Gerais - UFMG, Av. Universitária, 1000, Bairro Universitário, CP 135, CEP 39404-006, Montes Claros, MG, Brasil

*Corresponding author 
The high-fat diet consumption also may be associated with accumulation of triglycerides in the liver and the consequent development of non-alcoholic hepatic steatosis (MUSSO et al., 2003; McCUSKEY et al., 2004; CARMIEL-HAGGAI et al., 2005).

Caryocar brasiliense Camb., popularly known as pequi tree or just pequi, is a still little-studied species from the Brazilian Savannah (Cerrado biome). It has high oil content in the pulp and nut, especially unsaturated fatty acids. The oleic fatty acid accounts for around 55 and $44 \%$ and the palmitic fatty acid accounts for 35 and $44 \%$ of the composition of the pulp and nut oil, respectively. High amounts of alimentary fiber and antioxidant compounds (phenolic acids and carotenoids) are present, mainly in the pulp (ALMEIDA et al., 1998; LIMA et al., 2007). These compounds give to the pequi antioxidant properties that have been shown in several studies (PAULA-JUNIOR et al., 2006; KHOURI et al., 2007; ROESLER et al., 2008).

Pequi is a traditional fruit in the culture of the inhabitants of the Brazilian Savannah. It has great economic importance, and is widely used in regional cooking (ALMEIDA et al., 1998). Although it is a food with high lipid content, there are no reported studies about its effects on the lipid profile of the organism. The aim of the present study was, therefore, to investigate the effect of a pequi-rich diet on serum lipid profile, glycemia, and hepatic histology in mice.

\section{Materials and methods}

\subsection{Animals and diets}

Fresh C. brasiliense fruits were purchased from a local market in the city of Montes Claros, Minas Gerais state. The fruits were firstly sanitized with sodium hypochlorite and then cut to remove the stones. The pulp and nut used in the preparation of the diets were extracted from the stones.

Thirty-six female Albino swiss mice from 6-8 weeks-old and initial weight of $27.75 \pm 3.3 \mathrm{~g}$ were randomly divided into three groups of 12 animals each and fed ad libitum on standard chow diet (control group - CG), chow diet supplemented with 33\% pequi nut (nut group - NG), and chow diet with 33\% pequi pulp (pulp group - PG). The animals were housed in collective cages (five animals per cage) under a 12 hours light/dark cycle and a temperature of $23 \pm 1{ }^{\circ} \mathrm{C}$. The experiment lasted 6 weeks. The body weight and food intake were recorded weekly throughout the study. The body weight gain was determined as the difference between final and initial weight.

The experiment received the approval from the ethics committee of the State University of Montes Claros ( $N^{\circ} 225$ ).

\subsection{Plasma analysis}

After 6 weeks, the mice were fasted overnight and anesthetized using ethyl ether, and blood samples were collected by cardiac puncture. Serum concentration of total cholesterol (TC), HDL-cholesterol (HDL-c), triglyceride (TG), and plasma glucose were measured by enzyme-assay using commercial kits (Bioclin-Quibasa, Brasil). Atherogenic fraction (AF) was calculated as the difference between TC and HDL-C.

\subsection{Histological analysis}

After sacrifice, the liver was removed and weighed. Liver samples were fixed with $10 \%$ formalin and embedded in paraffin. The sections were cut $(6 \mu \mathrm{m})$ and stained with hematoxylin and eosin and were microscopically evaluated for steatosis.

\subsection{Statistical analysis}

The Grubb's test was used to detect outliers. In order to identify significant differences in the effects of the diets, a one-way ANOVA was used when a Kolmogorov smirnov test indicated that the variable was normally distributed. When the variables did not exhibit a Gaussian distribution, the groups were compared using the Kruskal-Wallis test. The differences among the three treated groups were analyzed using Tukey's Multiple Comparison test. Values of $\mathrm{p}<0.05$ were considered statistically significant. All analyses were performed using the GraphPad Prism 5.0 (GraphPad Software, San Diego California - USA) software. The results are expressed as mean \pm S.E.

\section{Results}

The macronutrients composition of the pequi pulp and nut and the diets offered are presented in Table 1.

To evaluate the food consumption of animals during the experimental period, food intake, energy intake, and energetic density were measured. The food intake was significantly different among the groups; it was higher in the control group, while the energy intake and caloric density were significantly higher in the pequi groups (Table 2). All mice gained weight throughout the study, either on control or experimental diet, although the weight gain was significantly higher in groups fed pequi-enriched diet (Table 2).

In order to characterize the serum lipid profile of mice, the total cholesterol, HDL-c and triglycerides were measured at the end of the experiment, and the atherogenic fraction was calculated. Serum lipid profile was significantly modified in the groups fed a diet containing either pequi pulp or nut (Table 3) compared to the control group. Total cholesterol and HDL-

Table 1. Macronutrient composition (wet basis) of the pequi pulp and nut and the diets offered (per $100 \mathrm{~g}$ ).

\begin{tabular}{|c|c|c|c|c|c|}
\hline & Pequi nut ${ }^{1}$ & Pequi pulp ${ }^{1}$ & Chow diet ${ }^{2}$ & Nut diet & Pulp diet \\
\hline Carbohydrate (g) & 8.33 & 11.45 & 38.75 & 24.56 & 29.62 \\
\hline Protein (g) & 25.27 & 3.0 & 23.0 & 24.28 & 23.68 \\
\hline Lipids (g) & 51.51 & 33.4 & 4.0 & 30.84 & 18.25 \\
\hline Total caloric (kcal) & 358.4 & 598.3 & 283.0 & 472.5 & 377.5 \\
\hline
\end{tabular}

${ }^{1}$ Lima et al. (2007). ${ }^{2}$ Ração comercial Labina ${ }^{\circ}$. 
cholesterol were significantly increased in the experimental groups. However, no differences were detected in serum atherogenic fraction and triglycerides. Similarly, the plasma glucose concentrations were not different among groups.

In order to evaluate possible effects of diets containing pequi on the liver, the livers were weighed and processed for histological examination. Although no significant changes in liver weight among the groups were noticed (Table 3), it was observed that mice fed pequi nut or pulp supplemented diet had hepatic parenchymal cells filled with multivesicular fat (microvesicular steatosis), mainly localized in the periportal area (Figure 1).

\section{Discussion}

This study assessed the potential effects of pequi-supplemented diets on the body weight gain, blood lipid and glucose profile, and hepatic histology since this fruit contains oleic acid-rich oil and also because several studies suggest that a diet rich in monounsaturated fatty acids is associated with a low rate of cardiovascular diseases (De LORGERIL et al., 1994).

Supplementation based on pequi contributed to increase the lipids content in the diet, and consequently the energetic density, compared to the control diet since the both the nut and pulp of pequi fruit have high oil content. Although the experimental animals ingested a lower amount of diet (in grams), the energy intake was higher than that of the control group due to the higher energetic density in the experimental diet provided by the high lipid content of pequi since lipids have higher caloric value than the other macronutrients. Therefore, the highest energetic intake resulted in the greater rate of weight gain observed in animals fed a diet containing pequi (CHARRONDIERE et al., 2004; LIMA et al., 2007; STRIJBOSCH et al., 2008). Moreover, the intake of a high-fat diet has been associated with overweight in mice, thus the higher weight gain in the animals in the experimental groups can be the result of high lipid content of pequi added to diet (KIM et al., 2008; HONG et al., 2009).

Dietary fat is one of the most important environmental factors associated with the incidence of cardiovascular diseases showing a positive influence when food has low saturated and high monounsaturated fatty acids content, while a high intake of saturated fat is highly prejudicial to health (MATTSON, 1989; GORINSTEIN et al., 2003). This study sought to evaluate a lipid source with a very heterogeneous composition in saturated and unsaturated fatty acids with predominance of monounsaturated fatty acids. The increase in serum total cholesterol levels in mice fed pequi-supplemented diets can be justified by the increase in HDL cholesterol since the atherogenic fraction was not modified by the experimental diets. This beneficial increase in the antiathrerogenic fraction probably resulted from the monounsaturated oleic fatty acid content in pequi pulp and nut. Nevertheless, this effect of monounsaturated fat on HDL cholesterol is yet controversial since some studies have reported no effect on serum HDL-c levels due to the ingestion of monounsaturated fatty acids (GRUNDY; DENKE, 1990; PUIGGRÓS et al., 2002). However, many other studies have shown an increase in HDL-c (MATA et al., 1992; PÉREZJIMÉNEZ et al., 1995) corroborating the results of this study. In addition, Gardner and Kraemer (1995) in a meta-analytical study showed no significant difference in the effect of monounsaturated fatty acids compared to polyunsaturated fatty acids, which have potent hypocholesterolemic activity, thereby supporting our results. Although some studies have showed no effect of monounsaturated fatty acids on levels of HDL cholesterol, specifically, it is quite clear that these fatty acids are able to modulate the serum lipid profile beneficially, especially in situations of hypercholesterolemia, reducing the risk of atherosclerosis and coronary artery disease (MORENO; MITJAVILA, 2003).

In addition to the beneficial increase in the levels of HDL-c, the lack of evidence of increased serum atherogenic fraction and triglycerides was an important result because high levels of atherogenic LDL-cholesterol in the blood are considered as major factor in atherosclerosis development. In particular, the oxidation of LDL is an important factor in this disease because it increases the expression of adhesion molecules that bind to circulating monocytes triggering the subsequent steps for the formation of lesions (CASÓS et al., 2008; ISHIGAKI et al., 2008; KATO et al., 2009). Therefore, the present study demonstrated that the diets containing pequi did not exert pro-atherogenic effect under these experimental conditions.

Table 2. Mean daily food intake, energy intake, and energetic density per animal during the experimental period, and mean weight gain in mice fed control diet (GC), nut pequi diet (NG), or pulp pequi diet (PG) at 6 weeks.

\begin{tabular}{ccccc}
\hline Groups & Food intake (g/animal) & Energy intake (kcal/animal) & Energetic density (kcal.g $\left.{ }^{-1}\right)$ & Gain body weight $(\mathrm{g})$ \\
\hline CG & $7.75 \pm 0.12^{\mathrm{a}}$ & $21.9 \pm 0.35^{\mathrm{a}}$ & $2.83^{\mathrm{a}}$ & $12.81 \pm 0.8^{\mathrm{a}}$ \\
NG & $5.52 \pm 0.07^{\mathrm{b}}$ & $23.2 \pm 0.2^{\mathrm{b}}$ & $4.72^{\mathrm{b}}$ & $16.19 \pm 0.9^{\mathrm{b}}$ \\
PG & $6.9 \pm 0.13^{\mathrm{c}}$ & $25.9 \pm 0.35^{\mathrm{c}}$ & $3.78^{\mathrm{c}}$ & $16.2 \pm 0.7^{\mathrm{b}}$ \\
\hline
\end{tabular}

Values are expressed as the mean \pm S.E. (Different letter express statistical difference, $\mathrm{p}<0.05$ ).

Table 3. Serum total cholesterol (TC), HDL-cholesterol (HDL-c), atherogenic fraction (AF), triglycerides (TG), plasma glucose, and liver weight in mice fed control diet (GC), nut pequi diet (NG), or pulp pequi diet (PG) at 6 weeks.

\begin{tabular}{ccccccc}
\hline Groups & TC $\left(\mathrm{mg} \cdot \mathrm{dL}^{-1}\right)$ & HDL-c $\left(\mathrm{mg} \cdot \mathrm{dL}^{-1}\right)$ & $\mathrm{AF}\left(\mathrm{mg} \cdot \mathrm{dL}^{-1}\right)$ & TG $\left(\mathrm{mg}^{\mathrm{dL}} \mathrm{dL}^{-1}\right)$ & Glucose $\left(\mathrm{mg}^{\left.\mathrm{d} \mathrm{dL}^{-1}\right)}\right.$ & Liver weight $(\mathrm{g})$ \\
\hline CG & $82.1 \pm 5.9$ & $41.8 \pm 6.4$ & $42.9 \pm 1.9$ & $94.0 \pm 15.5$ & $100.8 \pm 10.3$ & $1.83 \pm 0.09$ \\
NG & $116.6 \pm 7.3^{\mathrm{c}}$ & $73.4 \pm 8.5^{\mathrm{a}}$ & $43.2 \pm 5.6$ & $89.0 \pm 6.3$ & $97.4 \pm 6.6$ & $1.91 \pm 0.08$ \\
PG & $109.5 \pm 4.7^{\mathrm{b}}$ & $67.9 \pm 6.7^{\mathrm{a}}$ & $41.6 \pm 4.2$ & $99.1 \pm 13.7$ & $97.5 \pm 8.3$ & $1.81 \pm 0.08$ \\
\hline
\end{tabular}

Values are expressed as the mean \pm S.E. $\left({ }^{\mathrm{a}} \mathrm{p}<0.05 ;{ }^{b} \mathrm{p}<0.01\right.$; ${ }^{\mathrm{c}} \mathrm{p}<0.001$, vs. control). 

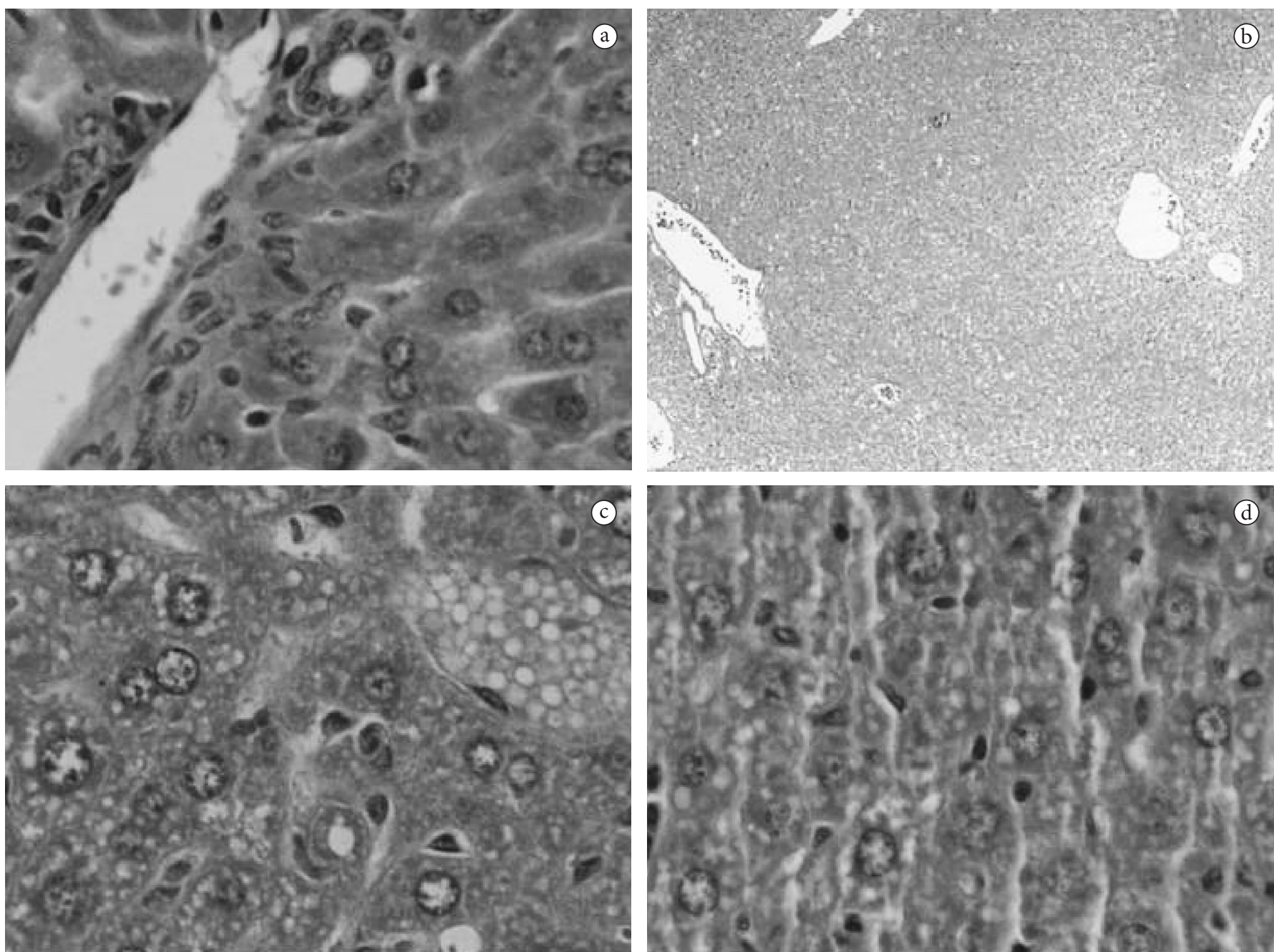

Figure 1. Hepatic photomicrographs of female mice after 6 weeks on the control or experimental diet. a) Normal liver with no lipid deposits in the control group magnification $\times 40$. b) Liver tissue with steatosis showing microvesicular fat around the periportal zone in the nut group, magnification $\times 4$. c) Microvesicular steatosis in the nut group with magnification of $\times 40$. d) Microvesicular steatosis in the pulp group with magnification of $\times 40$. Samples of liver stained with hematoxylin-eosin.

Although lipid-rich diet is associated with elevated levels of plasma glucose (GUO; HALL, 2009), this effect was not promoted by pequi in this experiment. This result may also be related to the high fiber content of this fruit because a high intake of fibers is associated with improvement in blood glucose level since they may promote a reduction in intestinal absorption of glucose (ALARCON-AGUILAR et al., 2003).

It has been proposed that a high-fat diet may play an important role in the pathogenesis of fatty liver disease (MUSSO et al., 2003; McCUSKEY et al., 2004; CARMIEL-HAGGAI et al., 2005). The highest concentration of fat in the diet enriched with pequi was able to increase the hepatic triglycerides accumulation in animals in the experimental groups. Moreover, this finding could be related to the not increased serum triglycerides rate in mice, thus confirming fat accumulation in liver cells. It has been reported that the fatty acid composition of the lipid diet is an important factor capable of modulating the liver lipid metabolism. A diet rich in oleic acid plays an important role in increasing the hepatic triglycerides content
(FERRAMOSCA et al., 2008), in accordance, therefore, with the effect of diets containing pequi found in this study since this fruit has a high oleic acid composition.

\section{Conclusions}

This is the first study on the effect of a diet containing either pequi pulp or nut on the lipid profile and hepatic histology in mice. The results demonstrated that a pequi pulp or nut-supplemented diet did not modified blood glucose or triglycerides levels in mice. Nevertheless, it was able to increase the serum HDL-cholesterol without changing the serum atherogenic fraction in this animal model. Triglycerides accumulation in the liver was also caused by higher fat intake corresponding to intake of pequi. Therefore, these findings suggest that further studies should be conducted on the effect of $C$. brasiliense fruit on dyslipidemia and atherosclerosis, as well as on oxidative stress due to its high content of antioxidant compounds. 


\section{Acknowledgements}

The authors are grateful to Hospital Universitário Clemente de Faria (HUCF) and Fundação de Amparo à Pesquisa do Estado de Minas Gerais - FAPEMIG. In addition, we thank Jacqueline I. Alvarez-Leite from Laboratório de Aterosclerose e Bioquímica Nutricional (LABiN), Universidade Federal de Minas Gerais (UFMG), and Lipid Metabolism Unit - Massachusetts General Hospital, Harvard Medical School, and Talita M.R. Ferreira and Alda J. Leonel, from LABiN, for their help in data analysis and critical reading of this manuscript.

\section{References}

ÁGUILA, M. B. et al. Lipid metabolism in rats fed diets containing different types of lipids. Arquivos Brasileiros de Cardiologia, v. 78, n. 1, p. 32-38, 2002.

ALARCON-AGUILAR, F. J. et al. Hypoglycemic activity of two polysaccharides isolated from Opuntia ficus-indica and O. streptacantha. Proceedings of the Western Pharmacology Society, v. 46, p. 139-142, 2003.

ALMEIDA, S. P. et al. Cerrado: espécies vegetais úteis. Planaltina: EMBRAPA-CPAC, 1998.

BINKOSKI, A. E. et al. Balance of unsaturated fatty acids is important to a cholesterol-lowering diet: comparison of mild-oleic sunflower oil and olive oil on cardiovascular disease risk factors. Journal of the American Dietetic Association, v. 105, n. 7, p. 1080-1086, 2005. http://dx.doi.org/10.1016/j.jada.2005.04.009

CASÓS, K. et al. Atherosclerosis prevention by a fish oil-rich diet in apoE-/- mice is associated with a reduction of endothelial adhesion molecules. Atherosclerosis, v. 201, n. 2, p. 306-317, 2008.

CARMIEL-HAGGAI, M.; CEDERBAUM, A. I.; NIETO, N. A high-fat diet leads to the progression of non-alcoholic fatty liver disease in obese rats. FASEB Journal, v. 19, n. 1, p. 136-138, 2005.

CHARRONDIERE, U. R. et al. Impact of different macronutrient definitions and energy conversion factors on energy supply estimations. Journal of Food Composition and Analysis, v.17, p. 339-360, 2004. http://dx.doi.org/10.1016/j.jfca.2004.03.011

DE LORGERIL, M. et al. Mediterranean alpha-linolenic acid-rich diet in secondary prevention of coronary heart disease. Lancet, v. 343, n. 8911 , p. 1454-1459, 1994. http://dx.doi.org/10.1016/S01406736(94)92580-1

FERRAMOSCA, A.; SAVY, V.; ZARA, V. Olive oil increases the hepatic triacylglycerol content in mice by a distinct influence on the synthesis and oxidation if fatty acids. Bioscience, Biotechnology, and Biochemistry, v. 72, n. 1, p. 62-69, 2008. PMid:18175925. http://dx.doi.org/10.1271/bbb.70369

GARDNER, C. D.; KRAEMER, H. C. Monounsaturated versus polyunsaturated dietary fat and serum lipids. Arteriosclerosis, Thrombosis, and Vascular Biology, v. 15, n. 11, p. 1917-1927, 1995. PMid:7583572. http://dx.doi.org/10.1161/01.ATV.15.11.1917

GERMAN, J. B; DILLARD, C. J. Saturated fats: what dietary intake? American Journal of Clinical Nutrition, v. 80, n. 3, p. 550-559, 2004. PMid:7583572.

GORINSTEIN, S. et al. Seed oils improved lipid metabolism and increase antioxidant potential in rats fed diets containing cholesterol. Nutrition Research, v. 23, n. 3, p. 317-330, 2003. http://dx.doi.org/10.1016/S0271-5317(02)00532-8

GRUNDY, S. M.; DENKE, M. A. Dietary influences on serum lipids and lipoproteins. Journal of Lipid Research, v. 31, p. 1149-1172, 1990.

GUO, J.; HALL, K. D. Estimating the continuos-time dynamics of energy and fat metabolism in mice. PLoS Computational Biology, v. 5, n. 9, p. 1000511-1000518, 2009. PMid:19763167. PMCid:2731929. http://dx.doi.org/10.1371/journal.pcbi.1000511
HONG, J. et al. Differential susceptibility to obesity between male, female and ovariectomized female mice. Nutrition Journal, v. 8, n. 11, 2009. Disponível em: <http://www.nutritionj.com/ content/8/1/11>. Acesso em: 4 jun. 2009.

ISHIGAKI, Y. et al. Impact of plasma oxidized low-density lipoprotein removal on atherosclerosis. Circulation, v. 118, n. 1, p. 75-83, 2008. PMid:18559699. http://dx.doi.org/10.1161/ CIRCULATIONAHA.107.745174

KATO, R. et al. Transient increase in plasma oxidized LDL during the progression of atherosclerosis in apolipoprotein $\mathrm{E}$ knockout mice. Arteriosclerosis, Thrombosis, and Vascular Biology, v. 29, n. 1, p. 35-39, 2009. PMid:18988894. http://dx.doi.org/10.1161/ ATVBAHA.108.164723

KIM, C. S. et al. Visceral Fat Accumulation Induced by a High-fat Diet Causes the Atrophy of Mesenteric Lymph Nodes in Obese Mice. Obesity, v. 16, n. 6, p. 1261-1269, 2008. PMid:18369345. http://dx.doi.org/10.1038/oby.2008.55

KHOURI, J. et al. Anticlastogenic potential and antioxidant effects of an aqueous extract of pulp from the pequi tree (Caryocar brasiliense Camb). Genetics and Molecular Biology, v. 30, n. 2, p. 442-448, 2007. http://dx.doi.org/10.1590/S1415-47572007000300024

LIMA, A. et al. Composição química e compostos bioativos presentes na polpa e na amêndoa do pequi (Caryocar brasiliense Camb.). Revista Brasileira de Fruticultura, v. 29, n. 3, p. 695-698, 2007. http://dx.doi.org/10.1590/S0100-29452007000300052

MATA, P. et al. Effects of long-term monounsaturated vs polyunsaturated enriched diets on lipoproteins in healthy men and women. The American Journal of Clinical Nutrition, v. 55, p. 846-850, 1992. PMid:1550067.

MATTSON, F. H. A changing role for dietary monounsaturated fatty acids. Journal of the American Dietetic Association, v. 89, n. 3, p. 387-391, 1989.

McCUSKEY, R. et al. Hepatic microvascular dysfunction during evolution of dietary steatohepatitis in mice. Hepatology, v. 40, n. 2, p. 386-393, 2004. http://dx.doi.org/10.1002/hep.20302

MORENO, J. J.; MITJAVILA, M. T. The degree of unsaturation of dietary fatty acids and the development of atherosclerosis. Journal of Nutritional Biochemistry, v. 14, p.182-195, 2003. http://dx.doi. org/10.1016/S0955-2863(02)00294-2

MUSSO, G. et al. Dietary habits and their relations to insulin resistance and postprandial lipemia in nonalcoholic steatohepatitis. Hepatology, v. 37, n. 4, p. 909-916, 2003. PMid:12668986. http://dx.doi.org/10.1053/jhep.2003.50132

PAULA-JUNIOR, W. et al. Leishmanicidal, antibacterial, and antioxidant activities of Caryocar brasiliense Cambess leaves hydroethanolic extract. Revista Brasileira de Farmacognosia, v. 16 , p. $625-630,2006$. http://dx.doi.org/10.1590/S0102$695 X 2006000500007$

PÉREZ-JIMÉNEZ, F. et al. Lipoprotein concentrations in normolipidemic males consuming oleic acid-rich diets from two diferents sources: olive oil and oleic acid-rich sunflower oil. The American Journal of Clinical Nutrition, v. 62, n. 4, p. 769-775, 1995.

PUIGGRÓS, C. et al. Effect of oleic-rich and Omega-3-rich diets on serum lipid pattern and oxidation in mildly hypercholesterolemic patients. Clinical Nutrition, v. 21, n. 1, p. 79-87, 2002.

ROESLER, R. et al. Antioxidant activity of Caryocar brasiliense (pequi) and characterization of components by electrospray ionization mass spectrometry. Food Chemistry, n. 110, p. 711-717, 2008. http://dx.doi.org/10.1016/j.foodchem.2008.02.048

STRIJBOSCH, R. A. M. et al. Fish oil prevents essential fatty acid deficiency and enhances growth: clinical and biochemical implications. Metabolism, v. 57, n. 5, p. 698-707, 2008. PMid:18442636. http://dx.doi.org/10.1016/j.metabol.2008.01.008 